\title{
Communicative Aspect of Chinese Narrative Songs Research
}

\author{
Natalia Y. Simonenko* \\ Volgograd State Social Pedagogical University \\ 27 Lenin Str., Volgograd, 400005, Russia
}

Received 04.06.2014, received in revised form 02.07.2014, accepted 28.12.2014

\begin{abstract}
Singing skill tends to be one of the main characteristics of Chinese people. In spite of being a great part of the culture, Chinese narrative songs have not been the subject of extensive research, either in China or abroad. The article describes the communicative and cultural peculiarities of Chinese narrative songs. We researched 73 songs of the period from 20th century to the beginning of 21st century, and it gave us the opportunity to see the changes in realities and values of Chinese society during this period of time. The leading research method is narrative analysis, in the process of which we analyze the songs according to fifteen variables. An analysis of the songs depicts the differences between Chinese narrative songs of different periods of the $20^{\text {th }}$ century. The results of this work can be applied for the further research of Chinese narrative discourse and narrative songs in Chinese and other languages.
\end{abstract}

Keywords: narrative, song, narrative song, Chinese, communicative aspect, homodiegetic, heterodiegetic, narrative analysis.

Research area: philology.

\section{Introduction}

A song is a part of nearly every culture in the world, and especially of Chinese culture, which can be described as a singing culture. The Chinese language is a tonal language in which a sentence sounds like a short song. That is why it is no wonder that singing skill tends to be one of the main characteristics of Chinese people. In spite of being a great part of the culture, Chinese narrative songs have not been the subject of extensive research, either in China or abroad.

\section{Statement of the problem}

The objective of this study is to discover the communicative and cultural peculiarities of Chinese narrative songs. The material of the research includes 73 Chinese narrative songs of the 20th -21 st century. We divided all the songs in accord with cultural and historical events into 2 big groups: before 1970 and after it. The year of 1970 was the end of the third five-year industrial plan in China. It was a period of defensive power building and allround development of agriculture and economy of China. After the third five-year industrial plan Chinese government began to do a "big west leap". And it influenced all the spheres of Chinese society, and music and songs as well. Due to these facts we divided all the analyzed songs into 2 groups: group 1, songs before 1970,

(c) Siberian Federal University. All rights reserved

* Corresponding author E-mail address: natalia-siyu@yandex.ru 
containing 33 songs, and group 2, songs after 1970, containing 40 songs.

\section{Methods}

The leading research method is narrative analysis. In accord with scientific works of Russian and international scientists who researched narrative [G. Genette, 1966, 1969; C. LeviStrauss, 1958; M. Jahn, 2005; O. A. Leontovich ,2011] we analyze the songs according to fifteen variables, such as: narrator, his gender, discourse type, characters, time and space, events, most frequently-used plotlines, main topics, genres, binary oppositions, cultural presuppositions, background knowledge, intertextual links and music videos. Application of this set of variables gives us the opportunity to analyze narrative songs from numerous angles and verify the results obtained according to their different methods of acquisition. In terms of the works mentioned we define a narrative song as a fiction of a communicative genre with its verbal, musical and emotional components by means of what the storyline of an event can be described.

\section{Discussion}

Non-fictional communication takes place in different narrative levels (Jahn, 2005). Relationships between these levels and the variables mentioned below make the unique world of every narrative. We define a narrative song as a communicative genre that has its verbal, musical and emotional components. Through the use of those, it depicts its plot, built on one event or several events. Chinese narrative songs are a beneficial material for research due to their compactness and their informative and emotional richness. Taking song lyrics as a material for the research gives us the opportunity to analyze a number of narratives, reveal their peculiar characteristics and regularities, and analyze their cultural particularities.
Though a Chinese narrative song appears to be such a rich material for research, we were able to find only three scientific works of Chinese linguists on this topic (Zhang Shihan, 1998; Meng Weiping, 2006; Quan Fu, 2007). Each of these works analyzes traditional narrative songs of one particular nationality in China, but provides no researches of narrative songs. Our work gathers Chinese narrative songs without taking into account the origins of singers, songwriters or composers. By researching the songs of the $20^{\text {th }}$ century, we learn more about the realities, problems and values of modern Chinese society. This makes our research important and valuable. Narrative analysis allows us to systematically record data, identify specific parts and topics of Chinese songs, construct a set of their main communicative and cultural characteristics, and find roots of the results obtained in cultural, political, social and economic changes in the history of China.

While we made our research, we mainly divided narrative songs into 2 groups: songs that were composed before 1970 and after 1970. We decided to divide them this way, because 1970 seems to be a crucial moment, as at that time main revolutions already took their places and a new epoch in Chinese history has began. An analysis of 73 Chinese narrative songs depicts the dominance of a homodiegetic narrative of an internal focalizer, who performs his figural autobiography, in both groups, before 1970 and after it. Such an autobiography usually describes the way the community which the narrator lives in sees him. These results indicate the collective nature of Chinese people and their dependence on community and public opinion. A further example from a song “绿帽子” (A Green Hat) proves the results obtained:啊 我的头上戴了顶绿帽子//你 说这心里憋屈不憋屈 (There's a green hat on my head // Guess, am I happy or not). As a green hat is known to be a symbol of marital infidelity in 
China, the question means that the protagonist is not happy; his family feels sorry for him, because such a concatenation of circumstances can be interpreted as loosing of face in China.

Analyzing time and place in Chinese narrative songs we found that in the majority of the songs from group 1 discursive and narrative time and place are congruent $(66,7 \%$ of group 1). And in most of songs from group 2 discursive and narrative time and place are not congruent (62,5\% of group 2$)$.

The song “涛声依旧” (“I can still hear the wash of the waves") from group 2 represents the result of our analysis: 无助的我已经疏远那 份情感 // 许多年以后才发觉又回到你面前 (“ Helplessly I know that this feeling has already grown cold, // and after all these years I'm standing in front of you again").

Due to the facts mentioned above we are of the opinion that the analysis of time and place give the ground to consider that more and more modern Chinese narrative songs do not describe concrete social and working activity, but became a reflection of what happened in the character's past and his wish to find the way out.

After C. Levi-Strauss we also analyzed binary oppositions. We found 3 main binary oppositions in the songs from group 1. They are:1) a man with communist party and without it (35,1\% of group 1); 2) Grate China and its enemies $(15,8 \%$ of group 1); past and present ( $8,8 \%$ of group 1$)$. The frequency of usage of these binary oppositions can be explained by the political course in China before 1970.

Concerning binary oppositions of the songs in group 2, most frequently-used oppositions are: past - present (13,1 \% of group 2), together - not near $(10,3 \%$ of group 2$)$, happiness - sorrow (joy - sadness) $(6,2 \%$ of group 2). Opposition past - present takes its roots from a periodical perception of time and events and appears to be the most popular opposition. It is mentioned in forty-five of researched songs, such as, for instance, a song春天里 (In Spring), in which the relations and difference between past and present situations are shown. In every couplet the protagonist moves us to his past young years: 还 记得许多年前的春天 // 那时的我还没剪去长发 (I still remember that spring. It passed us so many years ago // That time I hadn't cut my hair yet). And after it he tell us about how good is his life now and how little happiness it brings: 没有我那 可爱的小公主// 可我觉得一切没那么糟 (I didn't have this princess of mine, I have now, but I felt not so bad).

Most of the songs finish positively, though there are always some challenging situations and circumstances which main characters had to overcome to become happy and satisfied. We found such challenges as strong (serious) reasons for leaving a lover (“约定” A Promise, “大约在 冬季” Someday in winter), absence of mutual love (“一无所有” No one, “光阴的故事” Time Story) and everyday life problems (“相亲相爱一 辈子" Love forever).

Narrative analysis of 73 Chinese narrative songs gave the proofs for the existence of many cultural and communicative peculiarities of Chinese people at present. These are such peculiarities as 1) willingness to help: 俺们都 是活雷锋 // 俺们那嘎没有这种人 // 撞了车哪 能不救人? (All of us say that we are living like Lei Feng, // All of us say that we are not like that driver, // when you knocked down a man, how can you reject to rescue him?); 2) responsibility and co-operation: 一戞戞红灯一颗颗心, // 处 处是处处都是军民情 (One red light is one heart // And in the place where it shines, the army and the people are together), etc.

It also displayed the realities of this society and the way Chinese people see their life and themselves in detail, for example: 1) respect to the governmental laws and decisions: 亚洲 风四起 // 亚洲雄风震天吼 (Asian winds start 
blowing for the fourth, // Powerful Asian winds roar like a thunder); 2) respect to their parents and families: 却付出了热忱的生命 // 远处传来 你多么熟悉的声音 // 让我想起你多么慈祥的心 灵 ( You devoted your life to me // Your familiar voice comes from a very far place // And reminds me again and again how merciful was your soul), etc.

\section{Results}

1. An analysis of 73 Chinese narrative songs depicts the dominance of a homodiegetic narrative of an internal focalizer. These results indicate the collective nature of Chinese people and their dependence on community and public opinion.

2. The dominance of narratives about the past in modern Chinese sings denotes specific Chinese perception of time as a periodical process and willingness to analyze past events. Concerning binary oppositions of the songs, most frequently-used oppositions are: past - present, with - without someone, etc.

3. Narrative analysis of 73 Chinese narrative songs of the 20th - 21st century gave the proofs for the existence of main cultural and communicative peculiarities of Chinese people, such as: 1) willingness to help, 2) responsibility and co-operation. It also displayed the realities of this society and the way Chinese people see their life and themselves in detail: 1) respect to the governmental laws and decisions, 2) respect to their parents and families, etc.

Though we have been working on Chinese narrative songs for more than four years, we are only in the beginning, as Chinese songs in general and Chinese narrative songs in particular still deserve more detailed study. This study is a part of a growing body of research on reflection of Chinese culture in its language and art. This study will contribute to future research on cultural and communicative peculiarities of Chinese narrative discourse and similar topics. This work appears to be a valuable contribution to Chinese song research, to further research of Chinese linguaculture, and to narrative song lyrics research itself. The results of this work can also be applied for the research of narrative songs in different languages, as it gives a detailed description and compendious definition of a narrative song and accumulates a wide theoretical basis for its analysis.

\section{References}

1. Genette, G. Figure III. Paris, le Seuil, 1972. 286 p.

2. Jahn, M. (2005) Narratology: A Guide to the Theory of Narrative. English Department, University of Cologne. Available at: http://www.uni-koeln.de/ ame02/pppn.htm (accessed 23 November 2012).

3. Leontovich, O.A. Metody communicativnikh issledovanii [Methods of Communication Studies]. Moscow: Gnosis, 2011. 224 p.

4. Levi-Strauss, C. Structural Anthropology. Vol. 1. Trans. C. Jacobson and B. Schoepf. New York: Basic Books, 1958. 400 p.

5. Quan Fu. (2007) The Study on the Oral Account of the Narrative Folk Song. Inner Mongolia University Publ., 2007. 185 p. Available at: http://paper.dic123.com/lunwen_755096927/ (accessed 23 November 2012).

6. Meng Weiping. The Study on the Mongolian Long-form Koerqin Narraive Poem. Capital Normal Universuty Publ., 200665 p. Available at: http://paper.dic123.com/lunwen_899397387/ (accessed 21 November 2012). 
7. Zhang Shihan. The Study of Literature and Art Related to Buddhist Narrative Songs in Dunhuang. National Chung Hsing University Publ., 1998. 219 p. Available at: http://etds.lib.nchu.edu. tw/etdservice/view_metadata?etdun=U0005-1408200920503500 (accessed 20 November 2012).

\title{
Коммуникативный аспект исследования китайских нарративных песен
}

\author{
Н.Ю. Симоненко \\ Волгоградский государственный \\ социально-педагогический университет \\ Россия, 400005, Волгоград, пр. Ленина, 27
}

\begin{abstract}
Умение петь может считаться одной из главных характеристик китайцев. Несмотря на то, что они являются важной частью культуры, китайские нарративные песни мало исследованы как в Китае, так и за рубежом. Статья описывает коммуникативные и культурные особенности китайских нарративных песен. Нами было исследовано 73 песни периода с начала ХХ века до начала ХХІ века, что позволило проследить изменения в иенностях и реалиях китайского общества на протяжении данного периода времени. Ведущим методом является нарративный анализ, в ходе которого мы проанализировали песни по пятнадцати параметрам. Анализ песен выявил различия по исследуемым параметрам в китайских нарративных песнях разных периодов ХХ века. Результаты исследования могут быть применены при дальнейтем изучении особенностей нарративного дискурса и нарративных песен на китайском языке и других языках.
\end{abstract}

Ключевые слова: нарратив, песня, нарративная песня, китайский, коммуникативный аспект, гомодиегетический, гетеродиегетический, нарративный анализ.

Научная специальность: 10.00.00 - филологические науки. 